\title{
PENGARUH KADAR Cr (VI) AIR SUNGAI DAN JARAK SUMUR GALI DENGAN SUNGAI TERHADAP KADAR Cr (VI) AIR SUMUR GALI DI KELURAHAN BANYURIP KOTA PEKALONGAN TAHUN 2018
}

\author{
Kharisma Izzatunnisa' ${ }^{1}$ ), Sugeng Abdullah²), Tri Marthy Mulyasari ${ }^{3}$ ) \\ Jurusan Kesehatan Lingkungan, Politeknik Kesehatan Kemenkes Semarang, \\ Jl. Raya Baturaden KM 12 Purwokerto, Indonesia
}

\begin{abstract}
Abstrak
Kota Pekalongan merupakan kota sentra industri batik. Industri batik tersebut menghasilkan limbah cair berasal dari pewarna batik yang dibuang secara langsung ke sungai. Limbah cair batik mengandung logam berat seperti kromium. Tujuan Penelitian untuk mengetahui pengaruh kadar $\mathrm{Cr}$ (VI) air sungai dan jarak sumur gali dengan sungai terhadap kadar Cr (VI) air sumur gali di Kelurahan Banyurip Kota Pekalongan. Jenis penelitian ini termasuk penelitian observasional dengan pendekatan crossectional. Variabel bebas penelitian ini kadar Cr (VI) air sungai dan jarak sumur gali dengan sungai. Variabel terikat penelitian ini kadar Cr (VI) air sumur gali. Besar sampel air sungai sebanyak 3 sampel, banyak sampel air sumur gali sebanyak 52 sumur gali. Hasil Penelitian dengan menggunakan Regresi Linier Ganda menunjukan bahwa tidak ada pengaruh kadar Cr (VI) air sungai dan jarak sumur gali dengan sungai terhadap kadar Cr (VI) air sumur gali ( $p$ value = 0,779). Pengusaha batik sebaiknya mengolah limbah cair batik menggunakan metode fitoremediasi dengan tanaman (melati air (Echinodorus palaefolius), enceng gondok, dan lain- lain) sebelum limbah cair batik dibuang ke lingkungan. Masyarakat sebaiknya menggunakan sumber air bersih dari pemerintah seperti PAMSIMAS atau dapat mengonsumsi air minum dalam kemasan.
\end{abstract}

Kata Kunci : Kadar Cr (VI); Jarak, Air Sumur Gali; Air Sungai

\begin{abstract}
Pekalongan city is the city of batik industrial center. The batik industry produced liquid waste which derived from batik dyes and thrown away in river. Batik liquid waste contained heavy metals such as chromium. The Objective of this research was to find out the influence of $\mathrm{Cr}$ (VI) level of river water and the distance of dug well with river toward Cr (VI) level of dug well water in kelurahan Banyurip of Pekalongan city. Design of this research was based on including observational research with cross-sectional approaches. The Independent variables of research are $\mathrm{Cr}$ (VI) level of river water and the distance of dug well with river. The dependent variable of research is Cr (VI) level of dug well water. The sample river of research are 3 samples, and The sample dug wells of research are 52. The result of this research was by using statistical analysis of Multiple Linear Regression showed that there was no influence of Cr (VI) level of river water and the distance of dug well with river toward Cr (VI) level of dug well water ( $p$ value =0,779). Batik entrepreneurs needed to treat batik waste water by using phytoremediation method with plants (water jasmine (Echinodorus palaefolius), water hyacinth, etc.) before batik liquid waste was discharged into the environment. Public should use clean water sources from the government such as PAMSIMAS or the people could consume the bottled drinking water.
\end{abstract}

Keywords: Chromium hexavalent, Distance; Dug Well Water; River Water

\footnotetext{
1)Email: kharismaizza31@gmail.com

$\left.{ }^{2}\right)$ Email: sugengzend2016@gmail.com

$\left.{ }^{3}\right)$ Email: trimarthymulyasari@gmail.com
} 


\section{Pendahuluan}

Menurut Undang - Undang Republik Indonesia Nomor 36 Tahun 2009 tentang Kesehatan pasal 163 ayat (3) menyebutkan bahwa lingkungan sehat sebagaimana dimaksud pada ayat (2) bebas dari unsur-unsur yang menimbulkan gangguan kesehatan, antara lain limbah cair, limbah padat, limbah gas, sampah yang tidak diproses sesuai dengan persyaratan yang ditetapkan pemerintah, binatang pembawa penyakit, zat kimia yang berbahaya, kebisingan yang melebihi ambang batas, radiasi sinar pengion dan non pengion, air yang tercemar, udara yang tercemar dan makanan yang terkontaminasi.

Menurut Peraturan Pemerintah Nomor 82 Tahun 2001 tentang Pengelolaan Kualitas Air Dan Pengendalian Pencemaran Air bahwa Air merupakan sumber daya alam yang memiliki fungsi sangat penting bagi kehidupan dan perkehidupan manusia, serta untuk memajukan kesejahteraan umum, sehingga merupakan modal dasar dan faktor utama pembangunan. Air diperlukan untuk meningkatkan kualitas hidup manusia salah satunya untuk menunjang kegiatan industri dan teknologi (Wardhana, 1995, h.74). Sejalan dengan perkembangan penduduk dunia serta perkembangan industri yang sangat pesat, maka banyak sumber - sumber air yang mulai tercemar oleh limbah domestik maupun limbah industri (Nusa Idaman S, 2008, h.1). Hasil industri tidak hanya berupa barang (manufaktur), tetapi juga dalam bentuk jasa. Manufaktur berasal dari kata manufaktur yang berarti membuat dari tangan (manual) atau dengan mesin, sehingga menghasilkan suatu barang (Prawirosento, 2007). Contoh industri manufaktur adalah industri oli mesin, indusri obat, industri makanan kaleng, industri automotif, industri tekstil dan lain-lain. salah satu jenis industri tekstil yaitu industri batik.

Kota Pekalongan merupakan salah satu kota sentra industri batik yang cukup besar. Hampir semua masyarakat Pekalongan mempunyai mata pencaharian sebagai pengusaha industri batik. Kegiatan tersebut menghasilkan limbah cair berasal dari obat pemutih dan obat pewarna batik yang dapat meyebabkan pencemaran karena limbah tersebut langsung dibuang ke sungai-sungai di sekitarnya (F Nurkhayati, 2007).

Air limbah batik secara tidak langsung mempengaruhi kualitas air tanah, jika kotoran air limbah tidak terlalu tinggi maka akan diikat dan dinetralisir oleh tanah, akan tetapi jika melebihi kapasitas tanah, maka kandungan limbah tersebut akan mencapai air tanah dan mencemarinya (Tejokusuma B., 2007). Tanah adalah komponen padat yang dapat menerima pencemar baik pencemar jatuh dari udara maupun pencemar yang mengikuti aliran air (Sastrawijaya Y., 1991, h.67).

Industri batik merupakan salah satu penghasil limbah cair yang berpotensi mengandung logam berat (Wardani, dkk 2014). Dalam penelitian Puspita, dkk (2011), menyebutkan bahwa logam berat seperti logam berat krom berasal dari beberapa zat warna batik dan berasal dari proses pencucian akhir kain batik. Banyaknya perusahaan yang bergerak di bidang industri ini akan membawa permasalahan baru terhadap lingkungan sekitarnya, karena limbah batik dapat mencemari air sungai (Meiyanti, dkk, 2014). Industri batik yang tumbuh di permukiman penduduk meningkatkan jumlah limbah yang dibuang ke permukiman serta kondisi sumur gali yang tidak memenuhi syarat sanitasi dapat meningkatkan resiko penyebaran akibat air buangan yang banyak mengandung senyawa anorganik seperti logam berat krom. Sumur gali yang telah digunakan dalam waktu relatif lama lebih besar kemungkinan mengalami pencemaran karena selain bertambahnya sumber pencemar juga lebih mudahnya sumber pencemar masuk ke dalam sumur mengikuti aliran air tanah yang berbentuk memusat ke arah sumur (Tejokusuma B., 2007).

Berdasarkan penelitian Reni Lidyawati (2015) kadar kromium di badan air Sungai Asem Binatur melebihi kadar maksimum sesuai dengan Peraturan Pemerintah No. 82 tahun 2001 yaitu $\leq 0,05 \mathrm{mg} / \mathrm{l}$. Kandungan kromium $\left(\mathrm{Cr}^{+6}\right)$ tercatat $0,53 \mathrm{mg} / \mathrm{l}$ di bagian hulu dan $0,35 \mathrm{mg} / \mathrm{l}$ di bagian tengah serta 0,39 $\mathrm{mg} / \mathrm{l}$ di bagian hilir. Logam berat krom adalah bahan kimia yang bersifat persisten, bioakumulatif, dan toksik yang tinggi serta tidak mampu terurai dalam lingkungan dan akhirnya diakumulasi dalam tubuh manusia melalui rantai makanan (Palar, 2008, h.137). Limbah logam berat Cr (VI) merupakan salah satu jenis limbah berbahaya, dapat berasal dari industri batik, pelapisan logam (electroplating), dan penyamakan kulit (leather tanning). Tingkat toksisitas $\mathrm{Cr}(\mathrm{VI})$ sangat tinggi sehingga bersifat racun terhadap semua organisme untuk konsentrasi >0,05 ppm. $\mathrm{Cr}(\mathrm{VI})$ bersifat karsinogenik dan dapat menyebabkan iritasi pada kulit manusia (Metcalf \& Eddy, 1991).

Berdasarkan data umum dari Dinas Lingkungan Hidup Kota Pekalongan Tahun 2016 menyebutkan bahwa salah satu sungai yang paling tercemar limbah cair batik yang dibuang secara langsung melalui selokan yaitu Sungai pekalongan, sungai bremi, sungai 
meduri dan sungai banger. Sedangkan sungai yang tercemar di daerah yang dijadikan sebagai tempat permukiman yaitu Sungai Medono, Banyurip dan Podosugih.

Kelurahan Banyurip merupakan salah satu tempat pengrajin batik. Menurut survei pendahuluan yang dilakukan oleh peneliti pada 15 Oktober 2017 meliputi pengambilan sampel air sungai yang dilakukan salah satu titik secara acak serta pengamatan kondisi sungai dan sekitar sungai kelurahan Banyurip. hasil survei tersebut bahwa industri batik yang ada di Banyurip belum terdapat IPAL untuk mengolah limbah batik. Limbah batik langsung dibuang ke sungai tanpa mengalami pengolahan terlebih dahulu. Kondisi fisik air sungai tersebut berwarna hitam, dan berbau menyengat. Hasil pemeriksaan laboratorium bahwa kadar Cr (VI) air sungai di kelurahan Banyurip adalah 0,075 mg/l. Berdasarkan Peraturan Pemerintah Republik Indonesia Nomor 82 Tahun 2001 tentang Pengelolaan Kualitas Air Dan Pengendalian Pencemaran Air belum memenuhi baku mutu air kelas I, II, dan III dengan standar kadar $\mathrm{Cr}$ di air sungai $0,05 \mathrm{mg} / \mathrm{l}$. Sungai tersebut digunakan untuk perairan pertanian yang tidak maksimal. Sungai berdekatan dengan permukiman yang masih menggunakan sumur gali yaitu 94 rumah. Air sungai yang terdapat kadar $\mathrm{Cr}$ (VI) kemungkinan dapat mencemari air sumur gali di sekitar bantaran sungai.

Berdasarkan hasil survei tersebut, maka penulis tertarik untuk melakukan penelitian dengan judul "Pengaruh Kadar Cr (VI) Air Sungai Dan Jarak Sumur Gali Dengan Sungai Terhadap Kadar Cr (VI) Air Sumur Gali Di Kelurahan Banyurip Kota Pekalongan Tahun 2018"

Perumusan masalah: Apakah ada pengaruh kadar Cr (VI) air sungai dan jarak sumur gali dengan sungai terhadap kadar $\mathrm{Cr}$ (VI) air sumur gali di Kelurahan Banyurip Kota Pekalongan tahun 2018?

Tujuan dari penelitian: mengukur suhu air sungai, mengukur $\mathrm{pH}$ air sungai, mengukur debit aliran air sungai, mengukur kadar $\mathrm{Cr}$ (VI) pada air sungai, mengukur jarak sumur gali dengan sungai., mengukur suhu air sumur gali, mengukur $\mathrm{pH}$ air sumur gali, mengukur kadar $\mathrm{Cr}$ (VI) pada air sumur gali, mendeskripsikan kondisi konstruksi sumur gali, mendeskripsikan permeabilitas tanah di Banyurip Pekalongan, mendeskripsikan curah hujan di Banyurip Pekalongan.

\section{Gambar 1 KerangkaTeori}

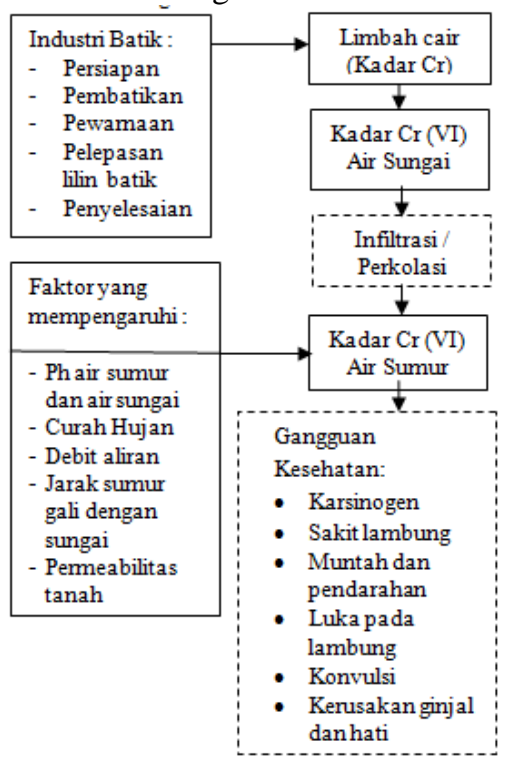

\section{Bahan dan Metode}

Jenis penelitian ini menurut ada tidaknya perlakuan termasuk penelitian observasional dengan pendekatan crossectional sedangkan menurut analisisnya termasuk penelitian inferensial.

Variabel bebas dalam penelitian ini adalah kadar $\mathrm{Cr}(\mathrm{VI})$ air sungai dan jarak antara sumur gali dengan sungai. Variabel terikat dalam penelitian ini adalah kadar $\mathrm{Cr}$ (VI) air sumur gali kelurahan Banyurip Pekalongan. Variabel pengganggu dalam penelitian ini adalah suhu air sungai dan air sumur gali, $\mathrm{pH}$ air sungai dan air sumur gali, debit aliran sungai, curah hujan, dan permeabilitas tanah.

Waktu penelitian pada persiapan sampai penyelasaian dilakukan bulan September Mei 2018. Lokasi yang digunakan dalam penelitian ini yaitu di RW 09 Kelurahan Banyurip Kota Pekalongan.

Populasi dalam penelitian ini yaitu jumlah seluruh air sungai dan air sumur di sekitar kelurahan Banyurip Kota Pekalongan. Sampel air sungai pada penelitian ini adalah air sungai pada sekitar kelurahan Banyurip yaitu hulu, tengah, dan hilir sungai yang melewati kelurahan Banyurip RW 9. Sampel air sumur gali yang digunakan pada penelitian ini sebanyak 52 Sumur Gali dengan kriteria:

a. Air sumur gali yang terletak di area permukiman penduduk

b. Air sumur digunakan untuk kebutuhan sehari - hari (dikonsumsi seperti minum dan masak) 
c. Sumur gali terletak lebih rendah dari sungai

d. Jarak sumur gali $\leq 95$ meter.

e. Bersedia untuk diambil sampelnya.

Cara pengumpulan data: observasi konstruksi sumur gali, Pengukuran dalam penelitian ini, Pengukuran debit aliran air sungai, Pengukuran antara jarak sumur gali ke sungai, Analisis data sekunder permeabilitas tanah, pengambilan dan pemeriksaan sampel air sungai dan air sumur di laboratorium

\section{Hasil dan Pembahasan}

Hasil pengukuran suhu air sungai di Kelurahan Banyurip Kota Pekalongan didapatkan rerata suhu air sungai di sebesar $29^{\circ} \mathrm{C}$ (suhu udara $=32^{\circ} \mathrm{C}$ ). Angka yang menunjukan hasil rerata suhu di Kelurahan Banyurip masih memenuhi persyaratan menurut Peraturan Pemerintah Nomor 82 Tahun 2001 Tentang Pengelolaan Kualitas Air dan Pengendalian Pencemaran Air.

Hasil pengukuran suhu air sumur gali dan air sungai menunjukan suhu yang bervariasi yaitu antara $27-29^{\circ} \mathrm{C}$. Hal tersebut disebabkan karena pengaruh dari waktu pengukuran saat pengambilan sampel. Arah penyinaran matahari disekitar sumur, sehingga mengakibatkan perbedaan temperatur pada air sumur dan air sungai.

Menurut Sittadewi, E. H. (2008) suhu air yang tinggi disebabkan oleh intensitas sinar matahari yang masuk ke badan air cukup tinggi karena lokasi pengukuran sampel merupakan daerah terbuka yang terkena sinar matahari secara langsung Intensitas paparan radiasi sinar matahari yang masuk ke badan air serta kerapatan vegetasi di sekitar bantaran sungai juga mempengaruhi suhu air sungai. Semakin banyak intensitas radiasi sinar matahari yang mengenai badan air maka akan membuat suhu air sungai akan semakin tinggi. Vegetasi mempunyai fungsi ekologi antara lain sebagai stabilisator temperatur dan kelembaban udara, pemasok oksigen, penyerap $\mathrm{CO}_{2}$ (dalam penelitian Nelly Marlina, dkk, 2017).

Hasil pengukuran pH Air Sungai di Kelurahan Banyurip Kota Pekalongan didapatkan rerata $\mathrm{pH}$ air sungai sebesar 6 . Berdasarkan rerata hasil pengukuran menunjukan bahwa $\mathrm{pH}$ air sungai di Kelurahan Banyurip adalah 6. Angka yang menunjukan hasil pH air sungai di Kelurahan Banyurip masih memenuhi persyaratan menurut Peraturan Pemerintah Nomor 82 Tahun 2001 Tentang Pengelolaan Kualitas Air dan Pengendalian Pencemaran Air. Baku mutu $\mathrm{pH}$ air sungai yaitu 6 - 9 .
$\mathrm{pH}$ air pada lokasi penelitian cenderung dalam katagori asam. Air yang mempunyai angka $\mathrm{pH}$ lebih kecil dari $\mathrm{pH}$ normal $(\mathrm{pH}=7)$ yaitu bersifat asam, sedangkan air yang angka $\mathrm{pH}$ lebih besar dari $\mathrm{pH}$ normal $(\mathrm{pH}=7)$ yaitu bersifat basa. Derajat keasaman $(\mathrm{pH})$ merupakan fungsi dari kandungan $\mathrm{CO}_{2}$ yang terlarut dalam air. Derajat keasaman juga berpengaruh terhadap toksisitas suatu senyawa kimia (Effendi, 2003). Nilai pH memiliki hubungan yang erat dengan sifat kelarutan logam berat. Pada $\mathrm{pH}$ rendah, ion bebas logam berat dilepaskan ke dalam kolom air. Selain hal tersebut, $\mathrm{pH}$ juga mempengaruhi toksisitas suatu senyawa kimia. Secara umum logam berat akan meningkat toksisitasnya pada $\mathrm{pH}$ rendah, sedangkan pada pH tinggi logam berat akan mengalami pengendapan (Kadang 2005). Connel dan Miler (1995) menyatakan bahwa kenaikan $\mathrm{pH}$ di perairan akan diikuti dengan penurunan kelarutan logam berat sehingga logam berat cenderung mengendap. Nilai $\mathrm{pH}$ perairan memilihi hubungan yang sangan erat dengan kelarutan logam berat.

Hasil pengukuran debit air sungai didapatkan rerata hasil pengukuran debit air sungai yang dilakukan peneliti di lokasi sebesar 93,76 1t/detik. Menurut penelitian Arief Happy R., dkk (2014) menyatakan bahwa semakin tinggi debit yang melewati aliran sungai pengenceranya makin tinggi pula. Nilai debit yang tinggi berdampak pada konsentrasi logam berat dalam air, kadar logam berat konsentrasinya akan menurun.

Effendi (2003) menyatakan bahwa dengan meningkatnya debit, kadar bahan bahan alam yang terlarut ke suatu badan air akibat erosi meningkat secara eksponensial. Namun, konsentrasi bahan - bahan antropogenik yang memasuki badan air tersebut mengalami penurunan karena terjadi proses pengenceran. Jika suatu bahan pencemar masuk ke badan air dengan kecepatan konstan, kadar bahan pencemar dapat ditentukan dengan membagi jumlah bahan pencemar.

Hasil pengukuran kadar $\mathrm{Cr}$ (VI) air sungai di Kelurahan Banyurip Kota Pekalongan didapatkan rerata $0,48 \mathrm{mg} / \mathrm{lt}$. Berdasarkan hasil kadar Cr (VI) pada air sungai di Kelurahan Banyurip masih memenuhi syarat menurut PP No. 82 tahun 2001 tentang Pengelolaan Kualitas Air dan Pengendalian Pencemaran Air. Kadar Cr (VI) yang diperbolehkan maksimal $1 \mathrm{mg} / \mathrm{lt}$.

Kromium (Cr) merupakan unsur yang melimpah yang terdapat di alam dengan bentuk oksida yaitu $\mathrm{Cr}(0), \mathrm{Cr}$ (III) atau $\mathrm{Cr}$ trivalent, $\mathrm{Cr}(\mathrm{VI})$ atau $\mathrm{Cr}$ heksavalen pada 
umumnya berasal dari proses industri (Wahyu Widowati, dkk, 2008, h. 102). Kromium bisa mencemari lingkungan udara, air, dan tanah. sebagian besar berupa $\mathrm{Cr}$ (III) dan $\mathrm{Cr}$ (VI). Pencemaran $\mathrm{Cr}$ (III) dan $\mathrm{Cr}$ (VI) di lingkungan, terutama berasal dari aktivitas dalam rumah tangga, industri kulit, industri tekstil, industri batik, industri baja, industri bahan kimia, serta industri yang menggunakan bahan baku $\mathrm{Cr}$ (Wahyu Widowati, dkk, 2008, h. 102).

Berdasarkan tabel 2.2 dapat dilihat proses pembuatan batik menghasilkan limbah terutama pada proses pewarnaan. Proses tersebut terdapat zat pencemar zat mordan yang terdapat logam berat $\mathrm{Cr}$. Limbah cair dari proses pewarnaan yang tidak dilakukan pengolahan terlebih dahulu dapat mencemari lingkungan terutama pada air sungai dan air sumur gali disekitar pembuatan batik.

Hasil pengukuran jarak sumur gali dengan sungai di Kelurahan Banyurip Kota Pekalongan didapatkan rerata jarak sumur gali dengan sungai yaitu $4.584 \mathrm{~cm}$. Berdasarkan hasil penelitian pada pengukuran jarak yang paling dekat pada sampel SF yaitu jarak 936 $\mathrm{cm}$ kadar Cr (VI) dalam air sebesar $0,21 \mathrm{mg} / \mathrm{l}$ dan yang paling terjauh pada jarak $17.317 \mathrm{~cm}$ dengan Kadar Cr (VI) sebesar 0,10 mg/lt. Kadar Cr (VI) dalam air sumur gali dilihat dari jarak paling dekat dan paling jauh dari air sungai tidak memenuhi syarat sebagai air bersih menurut persyaratan Peraturan Menteri Kesehatan Republik Indonesia Nomor 32 Tahun 2017 Tentang Standar Baku Mutu Kesehatan Lingkungan Dan Persyaratan Untuk Keperluan Higiene Sanitasi, Kolam Renang, Solus Per Aqua, Dan Pemandian Umum. Kadar Cr (VI) yang diperbolehkan yaitu maksimal $0,05 \mathrm{mg} / \mathrm{lt}$. Semakin dekat jarak sumur gali terhadap sumber pencemar maka semakin besar kemungkinan terjadinya pencemaran. Sumur gali menyediakan air yang berasal dari air tanah yang relatif dekat pada permukaan tanah, sehingga mudah terkena kontaminasi melalui perembesan dari sumber pencemar (Kusnoputranto, 1985, h. 26). Suatu air sungai yang tercemar air limbah, akibatnya adanya leakage dan infiltrasi pada dasar sungai maka limbah itu akan mengalir ke dalam tanah dan mencemari daerah-daerah di dalam tanah itu, sehingga hal ini tentu berisiko menyebabkan terjadinya pencemaran air tanah pada air sumur gali (Kodotie, 1996).

Hasil penelitian terhadap lokasi sumur gali di Kelurahan Banyurip dilalui sungai sebagian besar letak sumur gali berada pada lokasi yang rawan terhadap pencemaran yaitu kurang dari 95 meter dari sumber pencemaran kimia. Menurut Sugiharto (1987, h. 148), pencemaran yang diakibatkan kandungan bahan kimia dapat mencapai jarak 95 meter. Berdasarkan hal tersebut maka sumber air yang ada di masyarakat sebaiknya harus berjarak lebih dari 95 meter dari tempat pembuangan bahan kimia. Semakin dekat dengan sumber pencemar maka semakin berisiko terjadinya pencemaran pada air sumur gali.

Hasil pengukuran suhu air sumur gali di Kelurahan Banyurip didapatkan rerata suhu air sumur gali $28^{\circ} \mathrm{C}$ dan suhu udara $30^{\circ} \mathrm{C}$. Berdasarkan rerata hasil penelitian bahwa jumlah sampel sumur gali sebanyak 52 sumur gali. Hal ini menunjukan bahwa suhu air sumur gali di Kelurahan Banyurip masih memenuhi persyaratan menurut Peraturan Menteri Kesehatan Republik Indonesia Nomor 32 Tahun 2017 Tentang Standar Baku Mutu Kesehatan Lingkungan Dan Persyaratan Untuk Keperluan Higiene Sanitasi, Kolam Renang, Solus Per Aqua, Dan Pemandian Umum.

Suhu mempunyai pengaruh universal dalam mengatur proses alami di perairan, karena mempengaruhi komponen biotik dan abiotik. Peningkatan suhu perairan sebesar $10^{\circ} \mathrm{C}$ meyebabkan peningkatan konsumsi oksigen oleh organisme akuatik sekitar 2 - 3 lipat. Namun, peningkatan suhu ini disertai penurunan kadar oksigen terlarut sehingga keberadaan oksigen seringkali tidak mampu memenuhi kebutuhan oksigen bagi organisme akuatik untuk melakukan proses metabolisme dan respirasi. Apabila perairan tercemar oleh logam berat, maka sifat toksisitas dari logam berat terhadap biota air akan semakin meningkat seiring meningkatnya suhu (Effendi, 2003).

Sorense (1991) dalam penelitian Fauziah (2012) menyatakan bahwa peningkatan suhu perairan cenderung menaikan akumulasi toksisitas logam berat, hal ini terjadi karena meningkatnya laju metabolisme dari organisme air. Menurut Sarjono (2009) kenaikan suhu tidak hanya akan meningkatkan metabolisme biota perairan, namun juga dapat meningkatkan toksisitas logam berat di berairan. Suhu mempengarui konsentrasi logam berat di kolom air dan sedimen. Sementara suhu yang tinggi, senyawa logam berat akan larut di air.

Hasil pengukuran $\mathrm{pH}$ air sumur gali di Kelurahan Banyurip didapatkan rerata $\mathrm{pH}$ pada air sumur gali di sekitar sungai di Kelurahan Banyurip yaitu sebesar 7 . Berdasarkan hasil penelitian bahwa jumlah sampel sumur gali sebanyak 52 sumur gali. $\mathrm{pH}$ air dari 52 sampel tersebut masih 
memenuhi persyaratan menurut Peraturan Menteri Kesehatan Republik Indonesia Nomor 32 Tahun 2017 Tentang Standar Baku Mutu Kesehatan Lingkungan Dan Persyaratan Untuk Keperluan Higiene Sanitasi, Kolam Renang, Solus Per Aqua, Dan Pemandian Umum. baku mutu $\mathrm{pH}$ air sumur gali sebesar $6,5-9$.

$\mathrm{pH}$ air pada lokasi penelitian cenderung dalam katagori asam. Air yang mempunyai angka $\mathrm{pH}$ lebih kecil dari $\mathrm{pH}$ normal $(\mathrm{pH}=7$ ) yaitu bersifat asam, sedangkan air yang angka $\mathrm{pH}$ lebih besar dari $\mathrm{pH}$ normal $(\mathrm{pH}=7)$ yaitu bersifat basa. Derajat keasaman $(\mathrm{pH})$ merupakan fungsi dari kandungan $\mathrm{CO}_{2}$ yang terlarut dalam air. Derajat keasaman juga berpengaruh terhadap toksisitas suatu senyawa kimia (Effendi, 2003). Nilai pH memiliki hubungan yang erat dengan sifat kelarutan logam berat. Pada $\mathrm{pH}$ rendah, ion bebas logam berat dilepaskan ke dalam kolom air. Selain hal tersebut, $\mathrm{pH}$ juga mempengaruhi toksisitas suatu senyawa kimia. Secara umum logam berat akan meningkat toksisitasnya pada $\mathrm{pH}$ rendah, sedangkan pada pH tinggi logam berat akan mengalami pengendapan (Kadang 2005). Connel dan Miler (1995) menyatakan bahwa kenaikan $\mathrm{pH}$ di perairan akan diikuti dengan penurunan kelarutan logam berat sehingga logam berat cenderung mengendap. Nilai pH perairan memilihi hubungan yang sangan erat dengan kelarutan logam berat.

Hasil pengukuran kadar $\mathrm{Cr}$ (VI) air sumur gali di Kelurahan Banyurip Kota Pekalongan Tahun 2018 didapatkan rerata kadar Cr (VI) air sumur gali yaitu 0,14 mg/lt. Berdasarkan hasil penelitian pada tabel 4.9 kadar Cr (VI) air sumur gali di Kelurahan Banyurip tidak memenuhi persyaratan Peraturan Menteri Kesehatan Republik Indonesia Nomor 32 Tahun 2017 Tentang Standar Baku Mutu Kesehatan Lingkungan Dan Persyaratan Untuk Keperluan Higiene Sanitasi, Kolam Renang, Solus Per Aqua, Dan Pemandian Umum. Kadar Cr (VI) yang diperbolehkan yaitu maksimal 0,05 mg/lt.

Berdasarkan tabel 2.2 dapat dilihat proses pembuatan batik menghasilkan limbah terutama pada proses pewarnaan. Proses tersebut terdapat zat pencemar zat mordan yang terdapat logam berat $\mathrm{Cr}$. Limbah cair dari proses pewarnaan yang tidak dilakukan pengolahan terlebih dahulu dapat mencemari lingkungan terutama pada air sungai dan air sumur gali disekitar pembuatan batik.

Kromium heksavalen bersifat lebih toksik dibanding $\mathrm{Cr}$ (III). Paparan $\mathrm{Cr}$ bisa terjadi melalui inhalasi, per oral, serta kontak dengan kulit/mata. $\mathrm{Cr}$ (VI) bersifat karsinogenik terhadap kulit, mata, alat pernafasan, alat pencernaan serta bisa ditransfer ke embrio melalui plasenta (Wahyu Widowati, dkk, 2008, h. 103). Air sumur gali yang terindikasi logam berat kromium heksavalen yang tinggi, diharapkan masyarakat yang mempunyai industri batik rumahan tidak membuang limbah industri secara langsung. Hal tersebut sebaiknya mengolah limbah cair batik sebelum dibuang ke lingkungan. Berdasarkan penelitian Natalina, dkk (2017) menunjukan hasil fisiensi penurunan kromium heksavalen pada limbah cair batik adalah $52,858 \%$ dan $71,782 \%$, masing - masing untuk kitosan dari limbah udang windu dan kitosan murni. Berdasarkan penelitian Kristi Lestari (2017) hasil penelitian menunjukan tanaman melati air (Echinodorus palaefolius) memiliki efisiensi menurunkan kadar krom heksavalen limbah cair batik pada kontrol dan biomassa $0,5 \mathrm{~kg} ; 0,75 \mathrm{~kg}$ dan $1 \mathrm{~kg}$ sebesar $80 \%$.

Hasil inspeksi konstruksi sumur gali di Kelurahan Banyurip dapat dilihat pada tabel 9 sebagai berikut:

Tabel 1. Hasil inspeksi konstruksi sumur gali di Kelurahan Banyurip Kota Pekalongan Tahun 2018

\begin{tabular}{cccc}
\hline No. & Kriteria & $\begin{array}{c}\text { Jumlah } \\
\text { SGL }\end{array}$ & $\begin{array}{c}\text { Prosentase } \\
(\%)\end{array}$ \\
\hline 1. & $\begin{array}{c}\text { Memenuhi } \\
\text { Syarat }\end{array}$ & 3 & 5,77 \\
& $\begin{array}{c}\text { Tidak } \\
\text { Memenuhi } \\
\text { Syarat }\end{array}$ & 49 & 94,23 \\
\hline & Jumlah & 52 & 100 \\
\hline
\end{tabular}

Sumber: Data Primer 2018

Berdasarkan tabel 1 jumlah sumur gali yang dijadikan sampel sebanyak 52 sumur gali. Hasil inspeksi tersebut menunjukan bahwa konstruksi sumur gali pada $49(94,23 \%)$ sumur gali tidak memenuhi syarat dan 3 $(5,77 \%)$ sumur gali memenuhi syarat.

Sumur gali merupakan salah satu sumber penyediaan air bersih bagi masyarakat di pedesaan, maupun perkotaan. Sumur gali menyediakan air yang berasal dari lapisan tanah yang relatif dekat dengan permukaan tanah, oleh karena itu mudah terkena kontaminasi melalui rembesan yang berasal dari kotoran manusia, hewan, maupun untuk keperluan domestik rumah tangga (dalam penelitian ratnaningtyas, dkk 2014).

Sumur gali sebagai sumber air bersih harus ditunjang dengan syarat konstruksi, syarat lokasi untuk dibangunnya sebuah sumur gali, hal ini diperlukan agar kualitas air sumur gali aman sesuai dengan aturan yang ditetapkan (Waluyo, 2005). Menurut Gabriel (2001) dalam penelitian Dhani Hapsari (2015), 
Lokasi sumur sebaiknya pada daerah yang bebasbanjir sehingga tidak ada genangan air. Jarak sumur minimal 15 meter lebih tinggi dari sumber pencemaran (Gabriel, 2001).

Jumlah sumur gali yang dijadikan sampel sebanyak 52 sumur gali. Hasil inspeksi tersebut menunjukan bahwa kondisi sanitasi pada 49 sumur gali tidak memenuhi syarat dan 3 sumur gali memenuhi syarat . Data pengamatan inspeksi sanitasi sumur gali di Kelurahan Banyurip dapat dilihat pada Lampiran 17. Hasil inspeksi sumur gali yang tidak memenuhi syarat meliputi lokasi sumur merupakan salah satu pusat industri batik rumahan. Limbah industri batik yang dibuang melalui saluran pembuangan ke sungai tanpa pengolahan terlebih dahulu dapat meningkatkan potensi pencemaran logam berat ke sumur gali. Inspeksi konstruksi sumur gali meliputi dinding sumur tidak dilapisi dengan bahan yang kedap air atau tidak tembus air. Bibir sumur yang tidak memenuhi syarat sebagian besar memiliki tinggi dibawah $80 \mathrm{~cm}$. Lantai sumur yang tidak memenuhi syarat seperti yang tidak kedap air atau kondisi fisik lantai retak dan terdapat cekungan. Alat pengambil air sumur gali yang tidak dalam keadaan tergantung. Konstruksi sumur gali sebaiknya dilakukan pemeliharaan seperti lantai dan dinding dibersihkan dari kotoran. Saluran pembuangan air limbah di Kelurahan Banyurip yang berada di sekitar rumah warga didominasi limbah industri batik rumahan. Kondisi saluran pembuangan air limbah yang retak dapat memicu air limbah meresap ke dalam tanah dan meningkatkan resiko terscemarnya sumber air tanah. Selain itu lokasi merupakan daerah rawan banjir. Air limbah yang dibuang ke saluran pembuangan dapat meluap dan mencemari lingkungan sekitarnya termasuk sumber air.

Berdasarkan data - data tersebut secara umum bila dilihat dari segi konstruksi, sumur gali di lokasi penelitian lebih dari 50\% memenuhi syarat. Hal ini dikarenakan sebagian besar konstruksi sumur seperti dinding sumur yang kedap air. Masyarakat Kelurahan Banyurip menggunakan air sumur untuk kegiatan sehari hari seperti memasak, minum, mandi, mencuci dan lain lain. Kedalaman sumur gali di Kelurahan Banyurip rata - rata 4 -10 meter dari permukaan tanah.

Permeabilitas Tanah di Kota Pekalongan Berdasarkan Laporan Akhir Badan Lingkungan Hidup Studi Kerentanan Air Tanah Kota Pekalongan Tahun 2014 (dalam penelitian Reni Lidyawati, 2015) tanah Kelurahan Banyurip terdiri atas material liat, pasir, krikil dan krakal yang merupakan anggota aluvial kelabu dengan kelulusan air atau vadose zone merupakan lapisan pasir sehingga memiliki porous yang tinggi yang menyebabkan resiko pencemarannya juga tinggi . Berdasarkan tabel 2.3 dapat dilihat bahwa bahan pasir memiliki porositas sebesar $35 \%$, bahan kerikil memiliki porositas sebesar $25 \%$, dan bahan kerikil dan pasil memiliki porositas $0 \%$. Berdasarkan tabel 2.4 dapat dilihat perkiraan rata - rata permeabilitas bahan pasir sebesar $41 \mathrm{~m} /$ hari , bahan kerikil memiliki permeabilitas kerikil $4100 \mathrm{~m} / \mathrm{hari}$ dan bahan kerikil dan pasir memiliki permeabilitas $410 \mathrm{~m} /$ hari.

Berdasarkan data sekunder dari Badan Statistik Kota Pekalongan tahun 2017 didapatkan pemeriksaan hujan setiap bulan pada tahun 2017 sebagai berikut

Gambar 2. Grafik Curah Hujan Kota Pekalongan Tahun 2017

\section{Grafik Curah Hujan di Kota Pekalongan Tahun 2017}

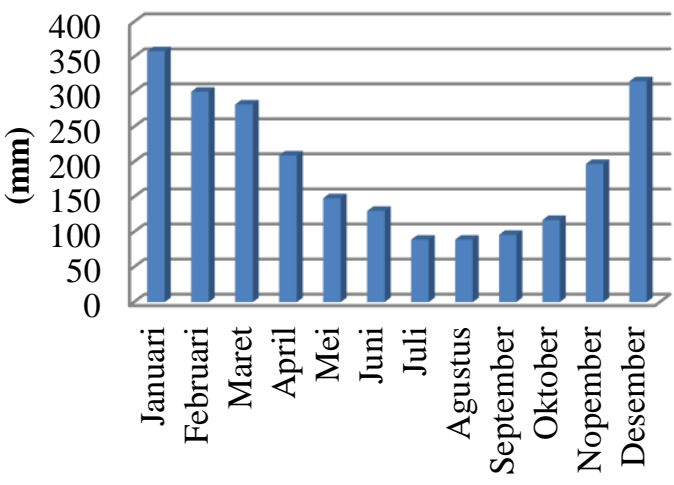

Sumber: Badan Statistik Kota Pekalongan 2017

Berdasarkan gambar 2 angka curah hujan paling tinggi terjadi pada bulan Januari 2017 sebesar $357 \mathrm{~mm}$ yang paling rendah pada bulan Juni dan Agustus 2017 sebesar 85 mm.

Hasil analisis multivariat pengaruh kadar $\mathrm{Cr}$ (VI) air sungai dan jarak sumur gali dengan sungai terhadap kadar Cr (VI) air sumur gali di Kelurahan Banyurip dapat dilihat pada tabel 10 sebagai berikut:

Tabel 2. Hasil Analisis Pengaruh Kadar $\mathrm{Cr}$ (VI) Air Sungai Dan Jarak Sumur Gali Dengan Sungai Terhadap Kadar Cr (VI) Air Sumur Gali Di Kelurahan Banyurip Kota Pekalongan Tahun 2018

\begin{tabular}{ccc}
\hline Variabel & Signifikan & B \\
\hline
\end{tabular}




\begin{tabular}{lcc}
\hline $\begin{array}{l}\text { Kadar Cr (VI) Air } \\
\text { Sungai dan Jarak }\end{array}$ & 0,779 & $-0,056$ \\
$\begin{array}{l}\text { SGL dengan } \\
\text { sungai }\end{array}$ & & \\
$\begin{array}{l}\text { Kadar Cr (VI) Air } \\
\text { Sungai }\end{array}$ & 0,669 & $-0,067$ \\
$\begin{array}{l}\text { Jarak SGL dengan } \\
\text { sungai }\end{array}$ & 0,674 & 0,066 \\
\hline \multicolumn{2}{l}{ Berdasarkan tabel 2} & \multicolumn{2}{l}{ menunjukan bahwa } \\
\hline
\end{tabular}

Tingkat signifikan koefisiensi korelasi satu sisi $(p)$ pada kadar Cr (VI) air sungai dan jarak sumur gali dengan sungai menghasilkan angka 0,779. Karena $p>0,05$, maka korelasi antara kadar $\mathrm{Cr}$ (VI) air sungai dan jarak sumur gali dengan sungai kadar Cr (VI) air sumur gali tidak signifikan atau dengan kata lain tidak ada pengaruh kadar Cr (VI) air sungai dan jarak sumur gali dengan sungai terhadap kadar Cr (VI) air sumur gali. Angka beta pada kadar Cr (VI) air sungai sebesar $(-0,067)$. Angka tersebut menunjukan bahwa semakin besar kadar $\mathrm{Cr}$ (VI) air sungai maka semakin besar kadar $\mathrm{Cr}$ (VI) air sumur gali. Angka Jarak sumur gali dengan sungai menghasilkan angka 0,066. Angka tersebut menunjukan angka positif sehingga semakin jauh jarak sumur gali dengan sungai semakin kecil kadar Cr (VI) air sumur gali.

Berdasarkan penelitian Puspita, dkk (2011), menyebutkan bahwa logam berat seperti logam krom berasal dari beberapa zat warna batik dan berasal dari proses pencucian akhir kain batik. Apabila bahan buangan yang mengandung logam berat tidak diolah dengan baik, maka bahan buangan tersebut dapat mencemari lingkungan. Daerah yang dijadikan sebagai tempat industri batik mempunyai permasalahan tersendiri terhadap pencemaran, akan lebih bermasalah lagi ketika hasil buangan yang berupa polutan yang sulit terurai dan akan mencemari lingkungan. Air limbah secara tidak langsung mempengaruhi kualitas air tanah, jika kotoran air limbah tidak terlalu tinggi maka akan diikat dan dinetralisir oleh tanah, akan tetapi jika melebihi kapasitas tanah, maka kandungan limbah tersebut akan mencapai air tanah dan mencemarinya (dalam penelitian Tejokusuma B., 2007). Tanah adalah komponen padat yang dapat menerima pencemar baik pencemar jatuh dari udara maupun pencemar yang mengikuti aliran air (Sastrawijawa Y., 1991).

Berdasarkan hasil penelitian jarak sumur gali dengan sungai diambil secara acak mulai dari jarak terdekat $936 \mathrm{~cm}$ hingga jarak terjauh $17.317 \mathrm{~cm}$. Menurut
Sugiharto (1987, h. 148), pencemaran yang diakibatkan kandungan bahan kimia dapat mencapai jarak 95 meter. Berdasarkan hal tersebut maka sumber air yang ada di masyarakat sebaiknya harus berjarak lebih dari 95 meter dari tempat pembuangan bahan kimia. Semakin dekat dengan sumber pencemar maka semakin berisiko terjadinya pencemaran pada air sumur gali.

Faktor penyebab terdeteksinya krom lebih besar pada sumur gali yaitu lokasi sumur yang dekat dengan industri batik rumahan. Limbah cair dari industri batik rumahan dibuang melalui saluran pembuangan air limbah di sekitar rumah warga. selain itu kondisi fisik sumur gali yang tidak memenuhi syarat seperti dinding sumur gali yang retak, bibir sumur yang tidak mencapai ketinggian $80 \mathrm{~cm}$, serta lantai sumur yang retak atau tidak kedap air. Sumur gali dapat dengan mudah terkena kontaminasi melalui rembesan, sehingga berpotensi mengalami penurunan kualitas air. Menurut Asdak (2004) faktor yang dapat mempengaruhi pencemaran sumur gali antara lain: kondisi geografis, hidrogeologi, topografi tanah, musim, kondisi fisik sumur.

\section{Simpulan dan Saran}

Berdasarkan Hasil analisis sebelumnya dapat disimpulkan bahwa, rerata suhu air sungai di Kelurahan Banyurip adalah $29^{\circ} \mathrm{C}$ ( suhu udara $=32^{\circ} \mathrm{C}$ ). Rerata $\mathrm{pH}$ air sungai di Kelurahan Banyurip adalah 6. Rerata debit air sungai di Kelurahan Banyurip sebesar 93,76 lt/detik. Kadar Cr (VI) air sungai di Kelurahan Banyurip yang paling rendah terdapat pada bagian hilir sebesar $0,33 \mathrm{mg} / \mathrm{lt}$ sedangkan paling tinggi terdapat pada bagian tengah sebesar $0,6 \mathrm{mg} / \mathrm{lt}$ dan rerata sebesar 0,47 mg/lt. Jarak sumur gali dengan sungai di Kelurahan Banyurip yang paling dekat adalah $936 \mathrm{~cm}$ dan paling jauh 17.317 $\mathrm{cm}$. Rerata Jarak sumur gali dengan sungai di Kelurahan Banyurip adalah $4.584 \mathrm{~cm}$. Rerata suhu air sumur gali di Kelurahan Banyurip pada 52 sampel sebesar $28^{\circ} \mathrm{C}$ dan suhu udara $30^{\circ} \mathrm{C}$. Rerata $\mathrm{pH}$ air sumur gali di Kelurahan Banyurip adalah 7. Kadar $\mathrm{Cr}$ (VI) air sumur gali di Kelurahan Banyurip yang paling rendah sebesar $0,07 \mathrm{mg} / \mathrm{lt}$, sedangkan paling tinggi sebesar $0,53 \mathrm{mg} / \mathrm{lt}$, dan rerata $0,14 \mathrm{mg} / \mathrm{lt}$. Hasil inspeksi sumur gali menunjukan bahwa konstruksi sumur gali 94,23\% tidak memenuhi syarat dan $5,77 \%$ memenuhi syarat. Permeabilitas bahan pasir sebesar $41 \mathrm{~m} /$ hari, bahan kerikil memiliki permeabilitas kerikil $4100 \mathrm{~m} / \mathrm{hari}$ dan bahan kerikil dan pasir memiliki 
permeabilitas $410 \mathrm{~m} /$ hari. Curah hujan di Kota Pekalongan Tahun 2017 adalah 2330 mm. Tidak ada pengaruh kadar $\mathrm{Cr}$ (VI) air sungai dan jarak sumur gali dengan sungai terhadap kadar $\mathrm{Cr}$ (VI) air sumur gali di RW 09 Kelurahan Banyurip tingkat signifikan sebesar 0,779 lebih dari 0,05.

Pengusaha batik sebaiknya mengolah limbah cair batik menggunakan metode fitoremediasi dengan tanaman (melati air (Echinodorus palaefolius), enceng gondok, dan lain- lain) sebelum limbah cair batik dibuang ke lingkungan, agar bahan kimia dari limbah cair batik dapat berkurang dan tidak menambah pencemaran lingkungan terutama sumber air bersih. Sebaiknya masyarakat tidak menggunakan sumber air bersih yang tercemar $\mathrm{Cr}$ (VI) untuk dikonsumsi sehari - hari. Masyarakat sebaiknya menggunakan sumber air bersih dari pemerintah seperti PAMSIMAS atau dapat mengonsumsi air minum dalam kemasan. Saran bagi Pemerintah Kelurahan Banyurip dan Dinas Lingkungan Hidup Kota Pekalongan yaitu Sebaiknya menginisiasi atau mengusulkan, memprioritaskan pembuatan IPAL Komunal. Saran untuk Dinas Kesehatan Kota Pekalongan, Sebaiknya melakukan pemantauan secara berkala minimal 1 kali dalam setahun terkait kualitas sumur gali, kualitas air sungai dan kualitas limbah cair yang dibuang ke lingkungan sehingga ada pengendalian dari pihak pemerintah dalam meningkatkan derajat kesehatan masyarakat setempat.

\section{Daftar Pustaka}

Ami Sukoasih. 2016. Hubungan Antara Suhu, Ph, Dan Berbagai Variasi Jarak Dengan Kadar Timbal (Pb) Pada Badan Air Sungai Rompang Dan Air Sumur Gali Industri Batik Sokaraja Tengah Tahun 2016. Skripsi. Purwokerto: Kementrian Kesehatan RI Politeknik Kesehatan Semarang Jurusan Kesehatan Lingkungan Purwokerto.

Asdak, Chay. 2004. Hidrologi dan Pengelolaan Daerah Aliran Sungai. Yogyakarta: Gadjah Mada University Press.

Badan Standarisasi Nasional . 2008. SNI 6989-57-2008 Tentang Metode Pengambilan Contoh Air Permukaan. Tangerang : Badan Standarisasi Nasional.
Badan Standarisasi Nasional . 2008. SNI 6989-58-2008 Tentang Metode Pengambilan Contoh Air Tanah. Tangerang : Badan Standarisasi Nasional

Budiman Chandra. 2006. Pengantar Kesehatan Lingkungan. Jakarta: Buku Kedokteran EGC.

Bambang Tejokusumo. 2007. Limbah cair industri serta dampaknya terhadap kualitas air tanah dangkal di desa Gumpang kecamatan Kartasura. Skripsi. Surakarta : Unversitas Sebelas Maret.

Darmono. 2008. Lingkungan Hidup dan Pencemaran. Jakarta: UI Press.

Denok Dwi Priyanti, dkk. 2014. "Pendugaan Pencemaran Air Tanah Di Tempat Pembuangan Sampah Landasan Ulin Timur Dengan Metode Geolistrik Konfigurasi Schlumberger”. Jurnal Fisika FLUX. http://ppjp.unlam.ac.id/journal diakses pada 20 Desember 2017 pukul 20.09

Dhani Hapsari. 2015. Kajian Kualitas Air Sumur Gali dan Perilaku Masyarakat di Sekitar Pabrik Semen Kelurahan Karangtalun Kecamatan Cilacap Utara Kabupaten Cilacap. Jurnal Sains dan Teknologi Lingkungan. http://media.neliti.com diakses pada 20 April 2018 pukul 04.30.

Direktur Jendral Pembrantasan Penyakit Menular \& Penyehatan Lingkungan Permukiman. 1994. Pedoman Pengendalian Dampak Pencemaran Limbah Industri Terhadap Kesehatan. Jakarta :Departemen Kesehatan Republik Indonesia.

Euthalia Hanggari Sittadewi. 2008. Kondisi Lahan Pasag Surut Kawasan Rawa Pening dan Potensi Pemanfaatannya. Jakarta: Pusat Teknologi Sumberdaya Lahan Kawasan dan Mitigasi Bencana Badan Pengkajian dan Penerapan Teknologi.

Hasibuan, Malayu S. P. 2006. Manajemen Sumber Daya Manusia, Edisi Revisi. Jakarta: Bumi Aksara.

Heryanto Palar. 2008. Pencemaran dan Toksikologi Logam Berat. Jakarta: Rineka Cipta. 
HJ Mukono. 2002. Prinsip Dasar Kesehatan Lingkungan. Surabaya: Airlangga University

Indonesia, Menteri Hukum dan Hak Asasi Manusia. 2009. Undang-Undang Republik Indonesia Nomor 36 Tahun 2009 tentang Kesehatan. Jakarta : Kementerian Hukum dan Hak Asasi Manusia.

Indonesia, Menteri Kesehatan Republik Indonesia. 2017. Peraturan Menteri Kesehatan Republik Indonesia No. 32 Tahun 2017 Tentang Persyaratan Kesehatan Air Untuk Keperluan Hygiene Sanitasi. Jakarta : Kementrian Kesehatan Republik Indonesia.

Indonesia, Menteri Lingkungan Hidup Republik Indonesia. 2014. Peraturan Menteri Lingkungan Hidup Republik Indonesia Nomor 5 Tahun 2014 Tentang Baku Mutu Air Limbah. Jakarta: Kementrian Lingkungan Hidup Republik Indonesia

Indonesia, Pemerintah Republik Indonesia. 2001. Peraturan Pemerintah Republik Indonesia Nomor 82 Tahun 2001 tentang Pengelolaan Kualitas Air Dan Pengendalian Pencemaran Air. Jakarta : Pemerintah Republik Indonesia.

Kelurahan Banyurip Kota Pekalongan. 2018. Profil Kelurahan Banyurip. Kota Pekalongan: Kelurahan Banyurip Kota Pekalongan.

Kristi Lestari. 2017. Efisiensi Tanaman Melati Air (Echinodoruspalaefolius) Dalam Menurunkan Kadar Krom Heksavalen $\left(\mathrm{Cr}^{+6}\right)$ Dan Kadar Warna Air Limbah Batik Di Desa Sokaraja Tengah Kecamatan Sokaraja Kebupaten Banyumas Tahun 2017. Skripsi. Purwokerto : Kementrian Kesehatan RI Politeknik Kesehatan Semarang Jurusan Kesehatan Lingkungan Purwokerto.

Natalina, dkk. 2017. Penurunan Kadar Kromium Heksavalen $\left(\mathrm{Cr}^{6+}\right)$ Dalam Limbah Batik Menggunakan Limbah Udang (Kitosan). http://ejournal.undip.ac.id/index.php/te knik diakses pada 20 April 2018 pukul 04.00 .
Nusa Idaman. 2008. Pengelolaan Air Limbah Domestik di DKI Jakarta. Jakarta: Pusat Teknologi Lingkungan.

Puspita U, dkk. Kemampuan Tumbuhan Air Sebagi Agen Fitoremidiator Logam Berat Kromium (Cr) Terdapat Pada Limbah Cair Industri Batik. Jurnal Terubuk. 2011. 39(1):58-64.

Putri Dwiramdhania.2016. Pengertian Industri dan Jenis Industri Menurut Drs. Suyadi Prawirosentono, M.B.A. http://pengertianindustri.blogspot.co.id/ diakses pada 20 November 2017 pukul 21.03

Ratnaningtyas, dkk. 2014. "Artikel Ilmiah Hasil Penelitian Mahasiswa 2014". http://repository.unej.ac.id/bitstream/ha ndle/123456789/69186 diakses pada 19 Oktober 2017 pukul 19.20.

Reni Lidyawati. 2015. Hubungan Jarak Dan Konstruksi Sumur Gali Dari Sungai Asem Binatur Terhadap Kadar Kromium $(\mathrm{Cr}+6)$ Air Sumur Gali Di Kelurahan Medono Dan Podosugih Kecamatan Pekalongan Barat Kota Pekalongan Tahun 2015. Skripsi. Semarang : Universitas Negeri Semarang

Robert J Kodoatie. 2008. Pengantar Hidrogeologi. Yokyakarta : Andi.

Santi Susiloputri, dkk. 2015. "Pemanfaatan Air Tanah Untuk Memenuhi Air Irigasi Di Kabupaten Kudus Jawa Tengah" http://eprints.undip.ac.id/34326/3/1965 diakses pada 27 November 2017 pukul 21.09

Sarjono. 2009. Analisis Kandungan Logam Berat $\mathrm{Cd}, \mathrm{Pb}$, dan $\mathrm{Hg}$ Pada Air dan Sedimen di Perairan Kamal Muara. Jakarta Utara. Skripsi. Institut Pertanian Bogor.

Soeparman Suparmin. 2002. Pembuangan Tinja dan Limbah Cair. Jakarta : EGC

Sosrodarsosno, Suyono. 1997. Pengukuran Topografi dan Teknik Pemetaan.Jakarta: PT Pradnya Paramita.

Sugiharto. 1987. Dasar-Dasar Pengelolaan Air Limbah. Jakarta: UI Press.

Totok Sutrisno. 2010. Teknologi Penyediaan Air Bersih. Jakarta : Rineka Cipta. 